\title{
Behavioral and morphological changes in fresh water fish, Channa punctatus under the exposure of Cadmium
}

\author{
Singh N. ${ }^{1}$ and Saxena B. ${ }^{2}$ 约
}

Received: 21.10 .2020

Revised: 22.11.2020

Accepted: 03.12.2020

\begin{abstract}
Heavy metal contamination in fresh water bodies is of great concern owing to their toxicity, persistence and bioaccumulation. The current study deals with the acute toxicity of cadmium to fresh water fish, Channa punctatus. The objective of this study was to grasp the link between mortality and abnormal behavioral and morphological changes of $C$. punctatus exposed to cadmium chloride. Static bioassay tests were carried out to evaluate $\mathrm{LC}_{50}$ value of Cadmium (Cd) for fresh water fish, $C$. punctatus as well as the behavioral responses and morphological changes were also observed. Fish after treatment with various concentrations of cadmium chloride for different exposure period the percent mortality was recorded. The lowest cadmium chloride concentration at which mortality was observed as $45 \mathrm{mg} / \mathrm{l}$. The first death of experimental fish was recorded as $125 \mathrm{mg} / \mathrm{l}$ at $24 \mathrm{hrs}$. of exposure. After $96 \mathrm{hrs}$. $\mathrm{LC}_{50}$ value of cadmium (Cd) was found to be $80.62 \mathrm{mg} / \mathrm{l}$. The major behavioral responses observed during the experiment were restlessness, jumping, erratic swimming, gulping of air at the surface, loss of equilibrium, sluggishness,opercular movements and fishes lied on the water surface before death and morphological changes like, discoloration of skin, pigmented patches on body, shedding of scales, sedimentation of chemical on body, mucous secretion, and ballooning were observed in exposed animals. The observed data showed that $\boldsymbol{C}$.punctatus can be used as a good bio-indicator for heavy metal contamination in fresh water bodies.
\end{abstract}

Key Words: Behavioral responses, Channa punctatus, Heavy metal contamination, Morphological changes.

\section{Introduction}

Now a day's freshwater bodies such as rivers, lakes and ponds are being polluted. These water bodies are not only being polluted but also become the disposal sites of domestic and industrial wastes by recent advances in industrialization, urbanization, agricultural and other developmental activities. Due to these activities, discharge of metals into the aquatic body has caused ecotoxicological effects. However, metals are unique among pollutants in that they occur naturally and in many instances are omni-present in the environment, but may cause adverse health effects as well. Kakade et al. (2020) reported the status of heavy metals in aquatic flora and fauna as hazardous and bio accumulative contaminants. Due to self-purification capacity and natural biological cycles, each aquatic ecosystem is capable of accepting a minimum amount of heavy metal concentration without any adverse effect.

Author's Address

${ }^{1}$ Department of Environmental Science, Bareilly College, Bareilly, (U.P.) India

${ }^{2}$ Department of Zoology, Bareilly College, Bareilly, (U.P.) India

E-mail.: beenamsaxena1972@gmail.com
Beyond the limit heavy metal contamination may cause decreased production, affects immune system, increased susceptibility to diseases and mortality in fishes. River Ganga is an important source of water for irrigation of surrounding farm lands as well as for fishing and aquaculture (Gupta et al., 2018). At Kachhla, River Ganga ghat is always full of rush on each Purnima (full moon) and becomes the site for religious bathing (Kanvar mela, Purnima mela etc.), also accustomed by watering of animals and washing the disposal of human and animal corpses. The different kind of waste creates environmental problems and increase pollution. Furthermore, wastewater such as municipal sewage, industrial effluents and agricultural run-off are the main cause of heavy metals in the water. Heavy metals accumulated in freshwater, indirectly enter in the food chain, and affect the fish being the top consumer in water directly from contaminated water (Afshan et al., 2014; Lacerda et al., 2020). Therefore, fishes are more susceptible aquatic organisms to toxic substances present in water. However, due to high protein content, low saturated fat and sufficient 
omega fatty acids fishes are an important part of the human diet. Hence, studies on the contamination of different fish species by heavy metals are of utmost importance (Sivaperumal et al., 2007). Cadmium has been listed in "Black-list" of European community (Mason, 1996). It is a non-essential, non-corrosive and highly toxic metal among heavy metal pollutant. Its main pollution sources into the aquatic environment include non-point sources like agricultural run-off, livestock breeding and point sources like industries such as, petroleum, mining and refining of ores, tannery, electronic (Ni-Cd batteries) industries, steel, paint, dye and plating processes, the use of phosphate fertilizers and gasoline containing lead by fishery boats (Bakshi and Panigrahi, 2018; Jaishankar et al., 2014; Mao et al., 2013).

Testing of toxicity is necessary tool for obtaining the action and outcome of toxicants in aquatic ecosystems, to attain water quality standards for chemicals and to spot suitable organisms as bioindicators. The aim of the toxicity test is to obtain different abnormalities caused due to the effect of pollutant or chemical and to find out the order of the lethality of the chemical (Absunullah et $a l ., 1981)$. Fish toxicity is a result of a sequence of events including different physical, chemical and biological processes. Estimation of median lethal concentration or dosage $\left(\mathrm{LC}_{50}\right.$ or $\left.\mathrm{LD}_{50}\right)$ is important as it can be used as an indicator to the level of resistance of population response to metals (Reda et al., 2010). The snakeheaded, air breathing fishes (C. punctatus) are entirely fresh water with a wide distribution in the old world, expanding from the Amur river in Eastern Siberia in the North through China to India (Kaushal and Mishra, 2013). Asian people have long considered it as an important edible fish (Laovitthayanggoon, 2006). The snakeheaded fish provides good source of income to many poor fish farmers. In India, this species has received an adequate attention in statistics and inland water fisheries policies etc. In contaminated water, fish may exhibit morphological changes and behavioral responses which can be used as biomarkers of contamination. Behavior allows an organism to adjust in changing environment, which may result drastic morphological changes in them. The use of these abnormalities in fish as biomarkers has become more prevalent in recent years. These biomarkers can provide suitable indication about the environmental condition (Sabullah et al., 2015). The changes act as diagnostic endpoints in screening the effect of polluted water on fishes and C. punctatus fish could be a good bio-indicator organism for heavy metal contamination of water. However, reporting in this particular context is meagre around Kachhla region in India. Therefore, there is need to access the concentration and bioaccumulation studies of some heavy metals and their toxic effects in fish from this big aquatic ecosystem. Keeping this in view, the present study was initiated to study the percent mortality at 96 hours and the behavioral and morphological changes in Channa punctatus due to exposure of sublethal dose of cadmium chloride.

\section{Material and Methods}

Healthy Channa punctatus (Bloch) were collected from the Ganga river at Kachchla, Badaun (U.P.) and brought to laboratory. Only healthy, uninjured and uninfected fish specimens (Length: $12-16 \mathrm{~cm}$, Weight: 50- $65 \mathrm{gm}$ ) were taken for experiment. Fishes were acclimatized in glass aquaria containing tap water for 15 days in the laboratory. The fishes were fed with fish food and water in the aquaria was changed at every $24 \mathrm{hrs}$, leaving no fecal matter, unconsumed food or dead fish. Proper aeration was maintained in test as well as control aquaria by aerators throughout the experiments.

The $96 \mathrm{hrs} \mathrm{LC}_{50}$ value of cadmium chloride was determined by static renewal bioassay following probit analysis (Finney, 1971). Different concentrations of cadmium chloride were prepared by dissolving weighed amount of $\mathrm{CdCl}_{2}$ in tap water. 10 Fishes were exposed to different concentrations of $\mathrm{Cd}$ as $\mathrm{CdCl}_{2}$ salt to know the acute toxicity at different exposure period i.e. 24, 48, 72 and 96 hrs.For studying the behavioural and morphological changes, fishes were divided into two groups: control and experimental group. Experimental group was exposed to $1 \backslash 5^{\text {th }}$ of $\mathrm{LC}_{50}$ dose. The behavioural and morphological changes were recorded simultaneously at different exposure period. In order to maintain the concentration of Cadmium, the water in the aquaria was changed every 24 hrs during the acute exposure and for chronic exposure water was changed twice a week. Fishes were regularly noticed for any variation in behavior and external morphology. 


\section{Results and Discussion}

Due to anthropogenic activities, fishes are one of the vertebrates group that respond firstly when the environment is contaminated with pollutants (Sehonova et al., 2017). Fishes are an important indicator of water pollution as it remains in direct water for food and oxygen and thus is highly susceptible to any change in aquatic environment. Cadmium does not break down in the environment and persist in the fish body for long periods and can bio-accumulate for many years after exposure to low levels of this metal (Wang et al., 2018; Markowicz et al., 2019). As, fishes are the part of important source of protein, So if human consume heavy metal contaminated fishes, it may lead to heavy metal accumulation in the human body. Therefore, heavy metal contaminated fish need to be carefully screened before consumption.

\section{$\mathbf{L C}_{\mathbf{5 0}}$ Estimation}

The test fish Channa punctatus was exposed to heavy metal Cadmium (Cd) as cadmium chloride $\left(\mathrm{CdCl}_{2}\right)$ upto $96 \mathrm{hrs}$. The percent mortality rate for each concentration of cadmium chloride are presented in Fig.1 and Table 1. The lowest cadmium chloride concentration at which mortality observed was $45 \mathrm{mg} / \mathrm{l}$. The first death of experimental fish was recorded in $125 \mathrm{mg} / 1$ at 24 hrs exposure. $96 \mathrm{hrs} \mathrm{LC}_{50}$ value was found to be $80.62 \mathrm{mg} / \mathrm{l}$. No mortality was observed over $96 \mathrm{hrs}$ in control group fishes. The data from these toxicity tests were evaluated using probit analysis. 96-hr $\mathrm{LC}_{50}$ value of cadmium chloride for Channa punctatus observed in present study almost corresponds with the $\mathrm{LC}_{50}$ value of cadmium chloride for Clarias batrachus $(82.66 \mathrm{mg} / \mathrm{l})$ reported by Dhara et al. (2014). Gill and Pant (1985) found $96 \mathrm{hrs} . \mathrm{LC}_{50}$ value of mercury 0.181 , $0.13 \& 0.51 \mathrm{ppm}$ for B. conchonus, E.maculatus \& S.gairdneri respectively. This variation in $\mathrm{LC}_{50}$ value may be due to change of fish species, geographical area as well as metal toxicity. Kaushal and Mishra (2013) observed fish mortality may have resulted by absorption, bio-accumulation of cadmium compounds or greater activity of chemical in body of fish.

\section{Behavioural Changes}

In present study, when Channa punctatus subjected to different cadmium chloride concentrations, it was reported that exposure to increasing amounts of cadmium resulted in increased mortality and caused various behavioural and morphological changes (Table 2). In both the control and the test aquaria, the behavior and condition of fishes were observed during the whole experiment. When fishes were exposed to sublethal concentration of cadmium chloride, they showed marked changes while in control group such changes were not reported. Just after introducing the fishes to the test aquaria, they showed the symptoms of swimming disability like uncontrolled irregular, erratic and darting swimming movements, restlessness, loss of equilibrium, drowning, hitting against the wall of test aquaria and trying to jump out of the test aquaria to avoid the chemical. The relation of avoidance reaction may be related to change in sensitivity of chemoreceptors. Similar results were reported by (Svecevieus, 2001, Agarwal, 1991). Loss of balance during swimming, observed during this study, might be due to some neurological impairment in the Central nervous system. Similar results were reported by Kawade and Khillare, 2014. Fast opercular movements, gulping of air and surfacing was also observed. Surfacing or gulping of air might occur due to a demand of higher oxygen level after exposure (Katja et al., 2005). Maruthanayagam et al. (2002) and Laovitthayanggoon (2006) also reported that with the increase of concentration of cadmium compounds on freshwater air breathing snake headed fish $C$. punctatus, it showed various behavioral responses and morphological changes. Hesni et al. (2011) studied the acute toxicity of lead nitrate on behavioural changes of milk fish. Other changes observed were hyper excitability, disturbed schooling, disrupted shoaling behavior, reduced feeding behavior and after few hours became lethargic. Sluggishness observed at the end of exposure periods may be due to loss of energy as a result of erratic swimming, jumping and restlessness. Behavioural activities increased upto $96 \mathrm{hrs}$ of exposure period. After few hours of the introduction of the fishes to the test aquaria, they became lethargic and settle down at the bottom of the tank. The discomfort seems to be higher upto 96 $\mathrm{h}$ of exposure. After every 24 hours, similar observation has been found. With the increase in the number of days the fishes show less activity and after 20 days they seems to get adapted to the toxic environment upto some extent. However, it was observed that whenever water was changed in the 
Table 1. Mortality of Channa punctatus (Bloch) in different concentration of cadmium chloride at $96 \mathrm{~h}$ exposure period

\begin{tabular}{|l|l|l|l|}
\hline Concentration of $\mathbf{C d C l}_{\mathbf{2}} \mathbf{( m g / l )}$ & $\mathbf{L o g}_{\mathbf{1 0}}$ Conc. & Percent Mortality & Probit Value \\
\hline Control & - & - & - \\
\hline 45 & 1.653212514 & 20 & 4.16 \\
\hline 65 & 1.812913357 & 30 & 4.48 \\
\hline 85 & 1.929418926 & 40 & 4.75 \\
\hline 105 & 2.021189299 & 60 & 5.25 \\
\hline 125 & 2.096910013 & 90 & 6.28 \\
\hline
\end{tabular}

Figure 1. Regression line between the Probit kill value of $C$. punctatus at different $\log _{10}$ concentrations of cadmium chloride.

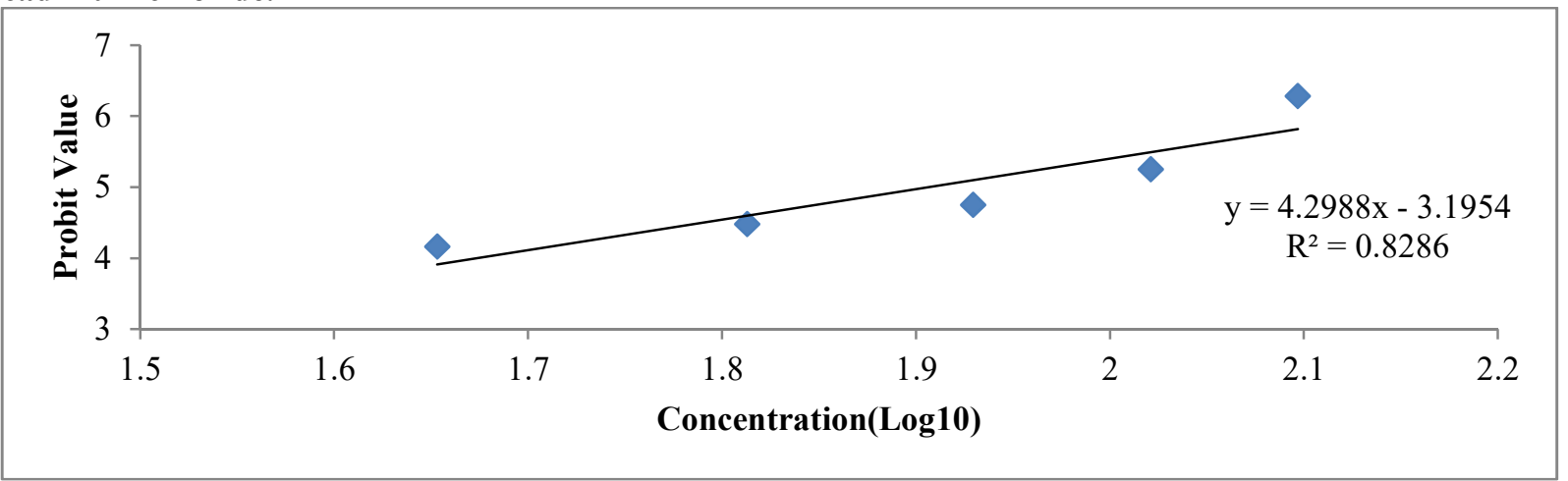

Table 2. Effect of sublethal dose of Cadmium Chloride exposure on behavioural responses of fresh water fish Channa punctatus.

\begin{tabular}{|c|c|c|c|c|c|c|c|c|}
\hline \multirow{3}{*}{ SN } & \multirow{3}{*}{ Behavioural Changes } & \multirow{3}{*}{ Control } & \multicolumn{6}{|c|}{ Exposure $\left(\mathrm{CdCl}_{2}\right)$ Period } \\
\hline & & & \multicolumn{4}{|c|}{ Acute Test } & \multicolumn{2}{|c|}{ Chronic Test } \\
\hline & & & 24 hrs & 48 hrs & 72 hrs & 96 hrs & 15 day & 30 day \\
\hline 1. & Loss of Equilibrium & - & ++ & ++++ & ++++ & ++++ & +++ & ++ \\
\hline 2. & Gulping air at Surface & - & +++ & +++ & ++++ & ++++ & +++ & ++ \\
\hline 3. & Erratic Swimming & - & ++ & +++ & ++++ & ++++ & ++ & ++ \\
\hline 4. & Opercular Movements & - & ++ & +++ & +++ & ++++ & ++ & ++ \\
\hline 5. & Restlesness & - & ++++ & +++ & ++++ & ++++ & +++ & ++ \\
\hline 6. & Jumping & - & ++++ & ++++ & ++++ & ++++ & +++ & ++ \\
\hline 7. & Sluggishness & - & ++ & ++ & +++ & ++++ & +++ & ++ \\
\hline
\end{tabular}

(-) Normal, (+) Nil, (++) Less Change, $(+++)$ Moderate Change and (++++) Prominent Change.

test aquaria, the fishes showed normal behavior for a few minutes to an hour and after some time they became lethargic. The effects are generally displayed as behavior responses and morphological changes that lead to genetic changes which become cytologically visible in the tissues. Fish is extremely sensitive in terms of behavior and any change in behavior of fishes is related with the toxicity. Behavioural changes have been established as sensitive indicator of chemically induced stress in aquatic organisms (Suedel et al. 1997; Remyla et al. 2008). Raised swimming activity stimulated by the toxicant would increase the requirement for oxygen, to meet the energy demand the energy demand of elevated muscular activity. Behavioral changes in animals are indicative of internal disturbances of the body functions such as inhibition of enzyme functions, impairment in neural transmission nervous impairment due to blockage of nervous transmission between the nervous system and various effectors sites and disturbance in metabolic pathways. 
Behavioral and morphological changes in fresh water fish

Table 3. Effect of sublethal dose of Cadmium Chloride exposure on morphological changes of freshwater fish Channa punctatus.

\begin{tabular}{|c|c|c|c|c|c|c|c|c|}
\hline \multirow[b]{3}{*}{ SN } & \multirow[b]{3}{*}{ Morphological changes } & \multirow[b]{3}{*}{ Control } & \multicolumn{6}{|c|}{ Exposure $\left(\mathrm{CdCl}_{2}\right)$ Period } \\
\hline & & & \multicolumn{3}{|c|}{ Acute Test } & & \multicolumn{2}{|c|}{ Chronic Test } \\
\hline & & & 24 hrs & 48 hrs & 72 hrs & 96 hrs & 15 day & 30 day \\
\hline 1. & Patches on body & - & ++ & ++ & +++ & +++ & ++++ & ++++ \\
\hline 2. & Discoloration of skin & - & ++ & ++ & +++ & +++ & +++ & ++++ \\
\hline 3. & Shedding of scale & - & ++ & ++ & $\overline{++}$ & ++ & +++ & ++++ \\
\hline 4. & Mucus secretion & - & ++ & ++ & ++ & +++ & +++ & ++++ \\
\hline 5. & $\begin{array}{l}\text { Sedimentation of chemical on } \\
\text { body }\end{array}$ & - & ++ & +++ & ++ & $\begin{array}{l}+++ \\
++\end{array}$ & $\begin{array}{l}+++ \\
++\end{array}$ & ++++ \\
\hline 6. & Clumping of Gills & - & ++ & ++++ & ++++ & ++++ & +++ & +++ \\
\hline
\end{tabular}

(-) Normal, (+) Nil, (++) Less Change, (+++) Moderate Change and (++++) Prominent Change.

\section{Morphological Changes}

During this study, we documented the various morphological changes in the body being exposed to different time period of cadmium chloride included discoloration of skin, thin chemical deposition on skin, less mucous secretion may cause the thin layer of chemical on aquarium bottom and shedding of scales (Table 3). Similar results were reported by Gupta and Dua (2015) when $C$. punctatus was exposed to Mercury. Other changes observed were clumping of gills, hyper extension of fins, split and necrosis of fins, lesion on skin, eye deformities and muscular tetany. Copious mucous secretion and its coagulation observed at higher chemical concentration. These changes seem to appear after 10 days of exposure and are seem to be more prominent at 30 days. The percentage of all these deformities was increased with the increase of exposure period. Similar observations were reported by Halappa and David (2009) and Anita et al. (2010). Maruthanayangam et al. (2002) also observed that toxicity of cadmium compounds to fish Channa punctatus is mainly caused due to gill damage which enabled the fish to obtain oxygen from water that resulted anoxia. The clumping of gills increases with the increase of exposure period of toxicant. The fish of test aquaria lost their natural coloration and become almost pale yellow in colour. Similar observations were reported by Brraich and Kaur (2015). In present study profuse mucous secretion is considered to be a defence mechanism to neutralize the effect of toxicant and to avoid it. Similar observations were made by many workers (Santha et al., 2000; Sivakumar et al., 2006; Shallangwa, 2011). Bisht and Agarwal (2007) suggested that mucous produced coagulates with the toxicant and prevents its cutaneous entry into the body. Furthermore deposition of mucus on the gills would reduce the gaseous exchange through them, thus reducing the oxygen supply. Through respiration cadmium compounds circulate all over body and may become one of the causes of death of animal due to hypoxia (Maina, 1997). Morphological changes points towards stress and injuries caused by metal toxicity. Thus, these parameters are used to determine toxicity (Kaur et al., 2013). Thus, toxicity studies can help to detect and evaluate the degree of pollution by providing reliable estimates of safe concentration from which water quality criteria can be derived. The knowledge obtained from dose response studies in animals is used to set standards for human exposure and the amount of chemical residue that is allowed in the environment. Behavioral toxicology is a rewarding tool for hazard assessment of water pollution. The behavioral changes in fish can be considered as biomarkers to access the health status of the fishes as well as aquatic bodies polluted by toxicants. Thus, environmental protection is the major requirement of the society.

\section{Conclusion}

In present study, results showed that when fishes exposed to sublethal concentration of cadmium chloride, they showed a marked change in their behavioral and morphological changes. These changes show direct response of the animals to the pollutants. Mortality was observed over $96 \mathrm{~h}$ period and the results revealed that the test species, $C$. 


\section{Singh and Saxena}

punctatus has shown differential mortality level at different concentration. The mortality has shown an increased level with an increase in the duration of the exposure period of cadmium chloride. Prolonged exposure induces behavioral responses and morphological changes in fishes. These changes and responses indicated stress in fishes which can further lead to death and reduction in fish fauna.

\section{References}

Absunullah, M., Negilsky, D. S., and Mobly, M.C. 1981. Toxicity of Zinc, Cadmium and Copper to Shrimp, Callianassaaustraliensis effects of individual metals. Marine Biology, 64(3): 299-304.

Afshan, S., Ali, S., Ameen, U., Farid, M., Bharwana, S., Hannan, F., Ahmad, R., 2014. Effect of different heavy metal pollution on fish. RJCES, 2: 74-79.

Agarwal, S.K. 1991. Bioassay evaluation of acute toxicity levels of mercuric chloride to an air breating fish, Channa punctatus (Bloch.): Mortality and Behaviour study. Journal of Environmental Biology, 12(2): 99-106.

Anita S., Sobha K. and Tilak, K.S. 2010. A study on acute toxicity, oxygen consumption and behavioural changes in the three major carps, Labeo rohita, Catla catla and Cirrhinus mrigala exposed to Fenvalerate. Bioresource Bulletin, 33-40.

Bakshi, A., Panigrahi, A., 2018. A comprehensive review on chromium induced alterations in fresh water fishes. Toxicology Reports, 5: 440-447.

Bisht, I. and Agarwal, S. K. 2007. Cytomorphological and histomorphological changes in mucous cells of general body epidermis of Barilius vagra (Cyprinidae, Pisces) following exposure to herbicide-BLUE VITROL (CuSO4): A statistical analysis. Journal of Experimental Zoology, 10: 27-36.

Brraich, O. S. and Kaur, M. 2015. Behavioural and Morphological Manifestations in LabeoRohita (Hamilton Buchanan) Under the Exposure of Lead Nitrate. International Journal of Scientific Research, 4 (8): 196198.

Dhara, K., Mukherjee, D. and Saha, N. C. 2014. Acute and chronic toxicity of cadmium to male Clarias batrachus Linn. with special reference to their haematological changes. International Journal of Scientific Research, 3 (12): 28-30.

Finney, D.J. 1971. Statistical methods for biological analysis. 3rd edition, London.
This type of study helps to understand the effect of heavy metal pollution on fishes so as to determine safe environmental concentration where there is no stress and lethality to fishes.

\section{Acknowledgment}

The authors are grateful to the Department of Zoology, Bareilly College, Bareilly, U.P. for providing the lab facilities.

Gill, T.S. and Pant, J.C. 1985. Mercury induced blood anomalies in the fresh water teleost, Barbus conchonius. Water Air and Soil Pollution, 24, 165-171.

Gupta, D., Dwivedi, A.K., and Tripathi, M. 2018. Taxonomic validation of five fish species of subfamily Barbinae from the Ganga river system of northern India using traditional and truss analyses. PLoS One, 13 (10): e0206031.

Gupta, N., and Dua, A. 2015. Impact of mercury on morphology of Channa punctatus. Global Journal of Environmental Science and Technology, 3(1): 5-7.

Halappa, R. and David, M. 2009. Behavioral responses of the freshwater fish, Cyprinuscarpio (Linn) following sublethal exposure to chlorpyrifos. Turkish Journal of Fisheries and Aquatic Sciences, 9: 233-238.

Hesni. M. A. et al. 2011. Study the Acute toxicity of lead nitrate metal salt on behavioral changes of the milkfish (Chanoschanos). World Journal of Fish and Marine Sciences (WJFMS), 3(6): 496-501.

Jaishankar, M., Tseten, T., Anbalagan, N., Mathew, B.B. and Beeregowda, K.N., 2014. Toxicity, mechanism and health effects of some heavy metals. Interdisciplinary Toxicology, 7: 60-72.

Kakade, A., Salama, E., Pengya, F., Liu, P. and Li, X. 2020. Long-term exposure of high concentration heavy metals induced toxicity, fatality, and gut microbial dysbiosis in common carp, Cyprinuscarpio. Environmental Pollution, 266: 115293.

Katja, S., Georg, B. O. S., Stephan, P. and Christian, E. W. S. 2005. Impact of PCB mixture (Aroclor 1254) and TBT and a mixture of both on swimming behaviour, body growth and enzymatic biotransformation activities (GST) of young carp (Cyprinus carpio). Aquatic Toxicology, 71:49-59.

Kaur, H., Kalotra, R.,Walia, G.K. andHanda, D. 2013. Dyeing industry effluent induced behavioral and morphological changes in the fish, Cirrhinus mrigal. International Journal of Zoology and Research, 3 (3):13-20. 
Kaushal, B.T, and Mishra, A. 2013. Investigation of acute toxicity of cadmium on snakehead fish Channa punctatusA comparative toxicity analysis on median lethal concentration. I.J.A.B.R, 3(2): 289-294.

Kawade, S. and Khillare, Y. 2014. Studies on Toxicity and Behavioural Responses under Cadmium Stress in Channa punctatus (Bloch.) The International Journal of Science \& Technoledge, 2 (13): 71-75.

Lacerda, D., Vergilio, C.D.S., da Silva Souza, T., Viana Costa, L.H., Rangel, T.P., Vaz de Oliveira, B.C., Ribeiro de Almeida, D.Q., Pestana, I.A., Gomes de Almeida, M. and de Rezende, C.E., 2020. Comparative metal accumulation and toxicogenetic damage induction in three neotropical fish species with distinct foraging habits and feeding preferences. Ecotoxicology and environmental safety, 195: 110449.

Laovitthyanggoon, S. 2006. Effects of Cadmium level on chromosomal structure of snakehead-fish (Ophiocephalus stiatus). Fac. of Guard. Studies, Mahidol Univ. Thailand.

Maina, J. N. 1997. The adaptive morphology of the gills of OreochromisalcalicusGrahami: A Cichlid fish which inhabits the hypersomatic, highly alkaline Kenayan lake Magadi. Advance in Fish Research, 2: 1-8.

Mao, C., Zhai, N., Yang, J., Feng, Y., Cao, Y., Han, X., Ren, G., Yang, G. and Meng, Q.X. 2013. Environmental kuznets curve analysis of the economic development and nonpoint source pollution in the ningxia Yellow river irrigation districts in China. BioMed research international, 7.

Markowicz, F., Król, G., Szyman' ska-Pulikowska, A., 2019. Biodegradable packageinnovative purpose or source of the problem. Journal of Ecological Engineering (JEE),20 (1) : 228-237.

Maruthanayagam, C., Sharmila, G., and Kumar, A. 2002. Toxicity of cadmium on the morphological and behavioural aspects in Labeorohita. Ecology and Ethology of Aquatic Biota, 119-127.

Mason, C. F. 1996. Biology of freshwater pollution. III Ed., Longman, U.K. 1-4.

Reda, F.A., Bakr, A.M., Kamel, S.A., Sheba and Doaa, R. A. 2010. A mathematical model for estimating the LC50 (or LD50) among an insect life cycle. Egyptian Academic Journal of Biological Sciences, 32: 75-81.

Remyla, S. R., Mathan, R., Kenneth, S. S. and Karunthchalam, S. K. 2008. Influence of Zink on Cadmium induced responces in a freshwater Teleost fish Catlacatla. Fish Physiology and Biochemistry, 34: 169-174.

Santha, K.M., Balaji, M., Saravanan, K.R., Soumady, D. and Ramudu, K. 2000: Effect of monocrotophos on the optomotorbehaviour of an air breathing fish Anabas testudineus (Bloch). Journal of Environmental Biology, 21(1): 65-68.

Sabullah, M. K., Ahmad, S. A., Shukor, M. Y., Gansau, A. J., Syed, M. A., Sulaiman, M. R. and Shamaan, N. A. 2015. Heavy metal biomarker: Fish behavior, cellular alteration, enzymatic reaction and proteomics approaches. International Food Research Journal, 22(2): 435-454.

Sehonova, P., Plhalova, L., Blahova, J., Doubkova, V., Marsalek, P., Prokes, M., Tichy, F., Skladana, M., Fiorino, E., Mikula, P., Vecerek, V., Faggio, C., and Svobodova, Z. 2017. Effects of selected tricyclic antidepressants on earlylife stages of common carp (Cyprinus carpio). Chemosphere, 185: 1072-1080.

Shallangwa, S.M. 2011. Toxicity of 2, 4dichlorophenoxyacetic acid on African mud Clariasgariepinus Journal of agricultural science, 6(4): 177-180.

Sivakumar, S., Karuppassamy, R. and Subhathra, S. 2006. Acute toxicity and behavioural changes in fresh water fish, Mystusvittatus (Bloch.) exposed to chromium (VI)oxide. Nature Environment and Pollution Technology, 5: 381388.

Sivaperumal, P., Sankar,T.V. and Nair,P.G.V. 2007. Heavy metal concentrations fish, shellfish and fish products from internal markets of India vis-a-vis international standards. Food Chemistry, 102: 612-620.

Suedel, B. C., Rodgers, Jr. J. H., and Deaver, E. 1997. Experimental that may affect toxicity of cadmium to freshwater organisms. Environmental Contamination and Toxicology, 33: 188-193.

Svecevieus, G. 2001. Avoidance response of rainbow trout, Oncorhyncusmykiss to heavy metal model mixtures. A comparision with acute toxicity tests. Bulletin of Environmental Contamination and Toxicology, 67: 680687.

Wang, J.R., Liu, G.Z., Zhang, C.J., 2018. Breakdown of Fermi liquid theory in topological multi-Weyl semimetals. Physical Reviews B, 98: 205113. 